Acta vet. scand. 1964, 5, 133-145.

From the State Veterinary Institute for Virus Research

Lindholm, pr. Kalvehave, Denmark.

\title{
DIFFERENTIATION OF VIRUS TYPES IN FOOT-AND-MOUTH DISEASE (FMD)
}

\author{
By \\ Knud Schjerning-Thiesen
}

\begin{abstract}
Differentiation of virus types in fmd is carried out in the daily routine as well as in more theoretical investigations with the application of the complement fixation reaction. As the reliability of observations within all laboratory work is fundamentally dependent on the exactness of the applied methods a continuous improvement of the complement fixation technique must be considered of the greatest importance for the type differentiation of fmd virus.

Below follows a detailed description of a technique applied in this institute at present (1963). As it has a relatively high degree of accuracy it gives both a greater and a faster possibility of differentiation.
\end{abstract}

\section{MATERIALS}

Veronal buffer. For the dilution of the components is used the veronal buffer described by Stein \& van Ngu (1950). Its pH 7.3-7.4 helps to secure a constant complement titre (Mayer et al. 1946). Production recipe for 2 litres of stock-solution: $\mathrm{NaCl} 42.500 \mathrm{~g}$; barbituric acid $2.875 \mathrm{~g}$; Na-barbiturate $1.875 \mathrm{~g} ; \mathrm{MgSo}_{4}, 7 \mathrm{H}_{2} \mathrm{O} 0.616 \mathrm{~g} ; \mathrm{CaCl}_{2} 0.083 \mathrm{~g}$. The finished stock-solution is sterilized by heat $\left(110^{\circ} \mathrm{C} / \mathrm{l}^{\mathrm{h}}\right)$ and is then kept at $4^{\circ} \mathrm{C}$. Before use the stock-solution is diluted in this way: to 2 parts are added 3 parts of redistilled water, to which has been added so much gelatine that the ultimate buffer per litre contains $1 \mathrm{~g}$ (Wallace et al. 1950, Osler et al. 1952).

Erythrocytes. $200 \mathrm{ml}$ blood is taken from a young sheep in $200 \mathrm{ml}$ modified Alsever's solution (Whitman 1947).*) According to the

*) Modified Alsever's solution: Dextrose $2.05 \mathrm{~g}$; Na-citrate $0.80 \mathrm{~g}$; Na-cloride $0.42 \mathrm{~g}$; citric acid $0.055 \mathrm{~g}$ and redistilled water up to $100 \mathrm{ml}$. Boiling for ab. 15 min. $\mathrm{pH} \mathrm{6.1.}$ 
author's experience blood stored in this way can be used as productive basis for almost identical erythrocyte-suspensions for ab. 8 weeks (Schjerning-Thiesen 1953).

Hemolysine. For the production is used the procedure given by Osler et al. (1952), and blood should be taken from the same sheep, which was bled for the production of Alsever-blood. The hemolysines keep their activity for at least 5 years without application of preservative, when stored at $-40^{\circ} \mathrm{C}$.

Complement. For each production are used at least 30 guinea-pigs which are exsanguinated by cardiac puncture. The blood is carefully put in large Petri dishes, which are protected from light and heat

(Halmann 1950), and which are left undisturbed until the coagulation is accomplished. Then the coagulum is scarified with a metal spatula, and the dishes are placed at $4^{\circ} \mathrm{C}$. Serum is pipetted off as it is separated, because the leaving of this together with the coagulum may produce the result that the hemolysine curve will not show the desired horizontal course (Leschly 1914). The complement is kept in portions corresponding to the daily consumption in hermetically sealed glasses at $-40^{\circ} \mathrm{C}$ and can in this manner be preserved throughout a year without any considerable loss of activity.

This procedure involves a possibility of eliminating the seasonal variation of complement activity mentioned in scientific literature (Rice \& Boulanger 1950).

Normal serum. By this is meant inactivated serum from normal guineapigs. This should possess the same or almost the same unspecific effect as the immune serum for which it is used as a substitute during the correction for unspecific fixation. It is therefore produced from the same animals as are later used for the production of immune serum and in the same way.

Immune serum. By this is meant inactivated serum from guinea-pigs, which are hyperimmune against fmd. Cattle virus is adapted to guineapigs by $2-6$ passage inoculations at most. A desirable adaptation is reached when virus constantly produces primary lesions ab. 24 hours p. i. and generalization processes $48-72$ hours p.i. For the hyperimmunization are chosen those guinea-pigs that during the adaptationprocess have shown disease with generalization and which have recovered ab. 3 weeks later. The first reinjection is given by inoculating intracutaneously into both plantae with virus (vesicular fluid + vesicular epithelium) resulting from the last adaptation passage. Animals which then get primary lesions are discarded. 3 days and 6 days later reinjections are again given, but these times intramuscularly with $0.30 \mathrm{ml}$ of the said virus suspension. 3 or 4 days later and after the animals have been fasted for 24 hours, blood samples are taken by cardiac puncture for the estimation of the titre. If the taken serums are satisfactory all animals are totally exsanguinated. If not, another intramuscular injection is given.

The titre is defined by the number of complement units which $0.50 \mathrm{ml}$ of a serum dilution $(1: 50)$ is able to fix specifically. A titre 
of at least 10 is required. Immuneserums can be kept at $-40^{\circ} \mathrm{C}$ for a couple of years without considerable change of activity.

Antigen. By this is meant aphtae epithelium from cattle tongue. The epithelium is ground in a mortar with quartz granules, the double amount $(\mathrm{w} / \mathrm{v})$ of veronal buffer is added, and the extract is centrifuged at 2000 r.p.m. for $90 \mathrm{~min}$. at 4 to $5^{\circ} \mathrm{C}$, and then at 10000 r.p.m. for 5 or $10 \mathrm{~min}$. also at 4 to $5^{\circ} \mathrm{C}$.

Inactivation by heating or treatment with kieselguhr is not used. The epithelium is stored without adding of liquid at $-40^{\circ} \mathrm{C}$, and will keep its total activity for at least 1 year.

\section{TECHNIQUE}

General technique. All diluting and mixing is performed at $0^{\circ} \mathrm{C}$ in an ice bath. Complement + serum + antigen are incubated for ab. 24 hours at $0^{\circ} \mathrm{C}$. After adding of hemolytic system, the mixture is incubated for 60 minutes at $32^{\circ} \mathrm{C}$. The degree of hemolyses is determined by means of a Beckman spectrophotometer at a wave length of 523 microns (Schjerning-Thiesen 1953). By the spectrophotometrical determination the value of optical density (D) is read. From the D-value $\left(D_{100}\right)$ corresponding to $100 \%$ hemolysis (reference) the degree of hemolysis ( $x$ ) corresponding to any observed $\mathrm{D}$-value is calculated:

$$
\mathrm{x}=\frac{\mathrm{D} \cdot 100}{\mathrm{D}_{100}} \%
$$

As there is a greater technical sensibility at $50 \%$ than at $100 \%$ hemolysis, the complement titre and also number of units of non-fixed complement are determined at $50 \%$ hemolysis. The complement quantity corresponding to $50 \%$ hemolysis is determined by graphic representation of the logarithms of the applied complement quantities ( $x$-axis) and the probits corresponding to the obtained degrees of hemolysis (y-axis), which are stated in Fisher \& Yates's statistical tables (1943). From the obtained rectilinear curve (the transformed hemolysis curve) the complement quantity corresponding to probit $5(=50 \%$ hemolysis $)$ is read.

The standardization of the erythrocyte-suspension. Alseverblood (20 ml is sufficient for ab. $100 \mathrm{ml}$ suspension) is centrifuged for 10 min. in a round-bottomed glass at 2000 r.p.m. at most. The packed erythrocytes are washed in buffer solutions until absolutely colourless rinsing fluid is obtained. 5 times in the fivefold vol. of buffer is most often sufficient.

For the standardization is used the technique worked out by Mayer et al. (1948) and Stein et al. (1950), the purpose of which at 
this point is to calculate the quantity of buffer that must be added to an erythrocyte-suspension of ab. $4 \%$ in order to get 0.5 million erythrocytes per $\mathrm{mm}^{3}$. The volume $\mathrm{X}$, to which the suspension must be diluted to obtain a $D$-value corresponding to the mentioned erythrocyte content, can be determined from the following equation, in which "Vol $4 \%$ " and "D $4 \%$ " refer to the known volume and the measured D-value of the applied $4 \%$ erythrocyte-suspension:

$$
\frac{\mathrm{X}}{\text { Vol } 4 \%}=\frac{\mathrm{D} 4 \%}{\text { Standard } \mathrm{D}^{\star} \text { ) }}
$$

Titration of hemolysine. From a twofold serial dilution of hemolysine (1:2 etc.) $0.8 \mathrm{ml}$ portions are pipetted into glasses containing $0.8 \mathrm{ml}$ of erythrocyte suspension. The glasses are incubated for $30 \mathrm{~min}$. at $37^{\circ} \mathrm{C}$. Then $1.60 \mathrm{ml}$ buffer solution and $0.80 \mathrm{ml}$ of complement 1:200 are added followed by incubation for $60 \mathrm{~min}$. at $32^{\circ} \mathrm{C}$.

The mixtures are centrifuged for 5 min. at 2000 r.p.m. The supernates are decanted into cuvettes, and the D-values are determined. Hemolysine quantities and D-values are marked in a system of coordinates on the $\mathrm{x}$-axis and $\mathrm{y}$-axis respectively. By the hemolysine titre is understood the smallest quantity that together with the applied complement quantity gives maximum hemolysis (ab. $50 \%$ ), or if expressed graphically, the smallest quantity found on the horizontal part of the curve. The titre must be at least $1: 1000$, and in the reactions hemolysine is used in a quantity corresponding to 2 times the titre.

The hemolytic system is produced by mixing equal parts of erythrocyte suspension ( 0.5 million erythrocytes per $\left.\mathrm{mm}^{3}\right)$ and hemolysine dilution. The mixture is carefully poured from one glass to another several times and is then put in water bath at $37^{\circ} \mathrm{C}$ for 30 minutes in a beaker which is shaken frequently. The system is produced at the latest possible time and is kept in ice water before and during use (Leschly 1914).

Complement titration. Preliminarily the D-value is determined for $100 \%$ hemolysis. $0.80 \mathrm{ml}$ of complement $1: 20,1.60 \mathrm{ml}$ of buffer solution and $1.60 \mathrm{ml}$ of prepared hemolytic system is mixed and incubated for $60 \mathrm{~min}$. at $32^{\circ} \mathrm{C}$. D of $100 \%$ hemolysis is read and used in later determinations of hemolysis degrees on the basis of observed $\mathrm{D}$-values. For the titration the total volume is likewise $4.00 \mathrm{ml}$ (complement $1: 200$ in quantities of from 0.50 up to $1.00 \mathrm{ml}$, buffer in quantities of from 1.90 down to $1.40 \mathrm{ml}$, prepared hemolytic system $1.60 \mathrm{ml}$ ). The mixture is incubated for 60 minutes at $32^{\circ} \mathrm{C}$. The dilution of the complement is not made until just before use, because the complement dilutions are inactivated more quickly.

Complement quantities and probits are marked on single logarithmic paper, and by graphic levelling the titre is determined, i. e. the complement quantity corresponding to $50 \%$ hemolysis (probit 5).

*) Standard $D$ is defined as the average optical density of 10 erythrocyte suspensions prepared from blood taken from the sheep in question and calibrated to contain 0.5 million erythrocytes per $\mathrm{mm}^{3}$. 
Determination of the complement fixing effect of immune serum, normal serum, and antigen, separately and mixed.

The complement quantity that is fixed by immune serum, by normal serum, by antigen, or by antigen + normal serum is an indication of the unspecific complement-fixing effect of these components, whereas the complement quantity fixed by immune serum + antigen is indicative of the specific + unspecific complement-fixing effect of these components. Specifically fixed is alone that quantity which has partaken in the antibody-antigen complex. The application of the complement fixation reaction on type differentiation is based on the determination of the specifically fixed complement quantity. An exact determination of this is dependent first and foremost on the exactness with which unspecific and specific + unspecific complement-fixing effect can be determined. These determinations are carried out by means of the technique given by Mayer et al. (1948). The technique as it is used by the present author, is described in principle as follows:

In glasses of $25 \mathrm{ml}$ is put either 1) complement alone, 2) complement + immune serum, 3) complement + normal serum, 4) complement + antigen, 5) complement + antigen + normal serum, or 6) complement + immune serum + antigen. A complement quantity is used corresponding to 50 units and immune serum + antigen corresponding to a fixation of between 10 and 40 complement units. To the glasses is then added veronal buffer up to a total volume of $5 \mathrm{ml}$.

After incubation for ab. 24 hours at $0^{\circ} \mathrm{C}$, two dilutions ( $\mathrm{I}$ and II) are made containing 1 and $2 \mathrm{ml}$ respectively per $10 \mathrm{ml}$ of dilution (see below). If a mixture after the incubation still contains 50 free units, the two dilutions will contain 1 and 2 units respectively per $\mathrm{ml}$ :

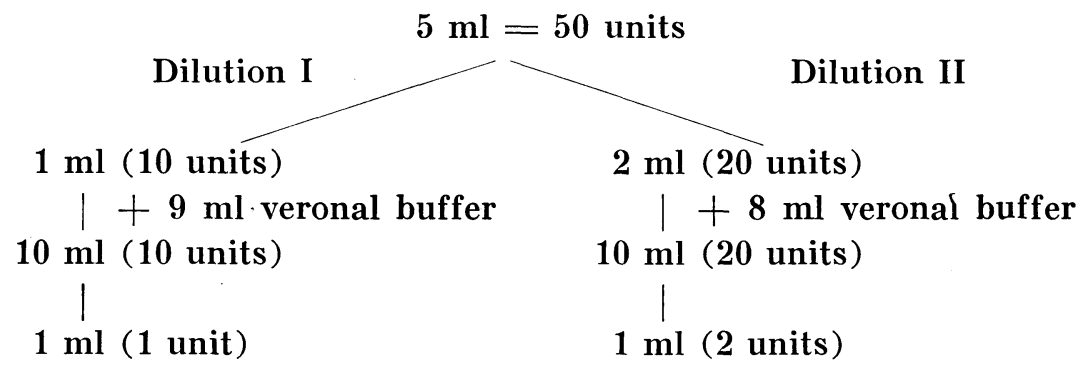


If however, the number of free units after the incubation is not 50, but $x$ times less $\left(\frac{50}{x}\right)$ because a fixation has occurred, it will be necessary to use $\mathrm{x} \mathrm{ml}$ of dilution I to obtain a complement unit ( $50 \%$ hemolysis). Consequently it can be deduced from this that the unknown quantity of remaining free units (b) must equal the original quantity of free units (50) divided by the quantity of dilution I (a) necessary to obtain $50 \%$ hemolysis $\left(b=\frac{50}{a}\right.$ ). If $50 \%$ hemolysis is obtained with one of the quantities of dilution I stated in column 1 of the table, one can read from column 2 the quantity of free complement units present in the mixture after the incubation. The calculation is made with the application of the above equation.

It has been previously mentioned that immune serum and antigen are not applied in larger quantities than what corresponds to 40 fixed units. Consequently a partial hemolysis will always occur with one of the stated quantities of dilution I.

Since however the work is carried out with a total volume of $4.00 \mathrm{ml}$, the hemolytic system of which is $1.60 \mathrm{ml}$, it is not possible to work solely with dilution I. Instead of the quantities of dilution I (1:10) given at the lower part of column 1, the quantities of dilution II $(1: 5)$ of column 3 which are only half as large can be used in the investigations. In the calculations, though only the quantities of dilution I given in column 1 are used.

Ta b l e 1. Determination of the number of remaining free units after incubation.

\begin{tabular}{ccc}
\hline ml, dilution I (a) & $\begin{array}{c}\text { number of remaining } \\
\text { free units }\left(\mathrm{b}=\frac{\mathbf{5 0}}{\mathrm{a}}\right)\end{array}$ & ml, dilution Il \\
\hline 0.75 & 66.5 & \\
0.90 & 55.5 & \\
1.00 & 50.0 & \\
1.10 & 45.5 & \\
1.25 & 40.0 & \\
1.50 & 33.3 & \\
1.75 & 28.5 & \\
2.00 & 25.0 & 1.25 \\
2.50 & 20.0 & 1.50 \\
3.00 & 16.7 & 1.75 \\
3.50 & 14.3 & 2.00 \\
4.00 & 12.5 & 2.25 \\
4.50 & 11.1 & \\
\hline
\end{tabular}


The following example illustrates the applied procedure of the determination of the number of remaining free units after the incubation.

Using the two dilutions (I and II) a preliminary determination is first made of the quantity of remaining free units. A scattered choice is made of the quantities of the two dilutions given in the table. Veronal buffer is added to the chosen quantities up to $2.40 \mathrm{ml}$, and 1.60 of hemolytic system (total volume: $4.00 \mathrm{ml}$ ). After incubation for 60 minutes at $32^{\circ} \mathrm{C}$ the glasses are centrifuged for 10 min. at 2000 r.p.m.. Finally $D$ and \%-hemolysis are determined for each glass.

If for instance a hemolysis of approximately $\mathbf{5 0 \%}$ is observed with $1.75 \mathrm{ml}$ of dilution $\mathrm{I}$, there will be ab. 28.5 free units in the mixture.

After the preliminary determination an exact determination is made where the quantities used group themselves nearer the observed value, in the present example: $1.75 \mathrm{ml}$. The procedure is as mentioned under the preliminary determination.

By marking on single logarithmic paper the chosen quantities of dilution $I$ (x-axis) and the probits corresponding to these (y-axis), it will be possible to determine the quantity $(x)$ of dilution I that is necessary for $50 \%$ hemolysis (probit 5). Each determination is based on at least 5 or 6 observations. From the fraction $\frac{50}{x}$ the number of remaining free complement units is then calculated.

When the number of free units in the mixtures have been determined, it is possibly by simple subtraction to determine the number of specifically fixed units. From the glass with complement alone a possible loss of complement units as a result of lability is determined and used for correction.

\section{PROCEDURE FOR DIFFERENTIATION OF VIRUS TYPES.}

Applying known serums ( $\mathrm{O}, \mathrm{A}, \mathrm{C}$ etc.) a group differentiation is made with the unknown antigen ( $x$-antigen) according to the technique given by Traub \& Möhlmann (1943). In order ultimately to decide the type of the antigen (type differentiation) a titration is made of one or more of the serums belonging to the group in question with the application of homologous antigen as well as $\mathrm{x}$-antigen. 
Below is described the procedure applied in this institute for the type differentiation. The description comprises a titration of $\mathrm{O}_{1}$-immune serum with the application of homologous and unknown antigen (types $\mathrm{O}_{1}$ and $\mathrm{O}_{\mathrm{x}}$ ).

The titration of $\mathrm{O}_{1}$-immune serum or the determination of the specific complement fixation of $\mathrm{O}_{1}$-immune serum with $\mathrm{O}_{1}$ and $\mathrm{O}_{\mathrm{x}}$-antigen is carried out using several quantities of serum diluted 1:50. The chosen quantities of immune serum should show an unspecific effect of less than 2 units. Considering the disproportions caused by an excess of antigen (SchjerningThiesen 1960), the optimum antigen quantities corresponding to the applied serum quantities are first determined. From fig. 1

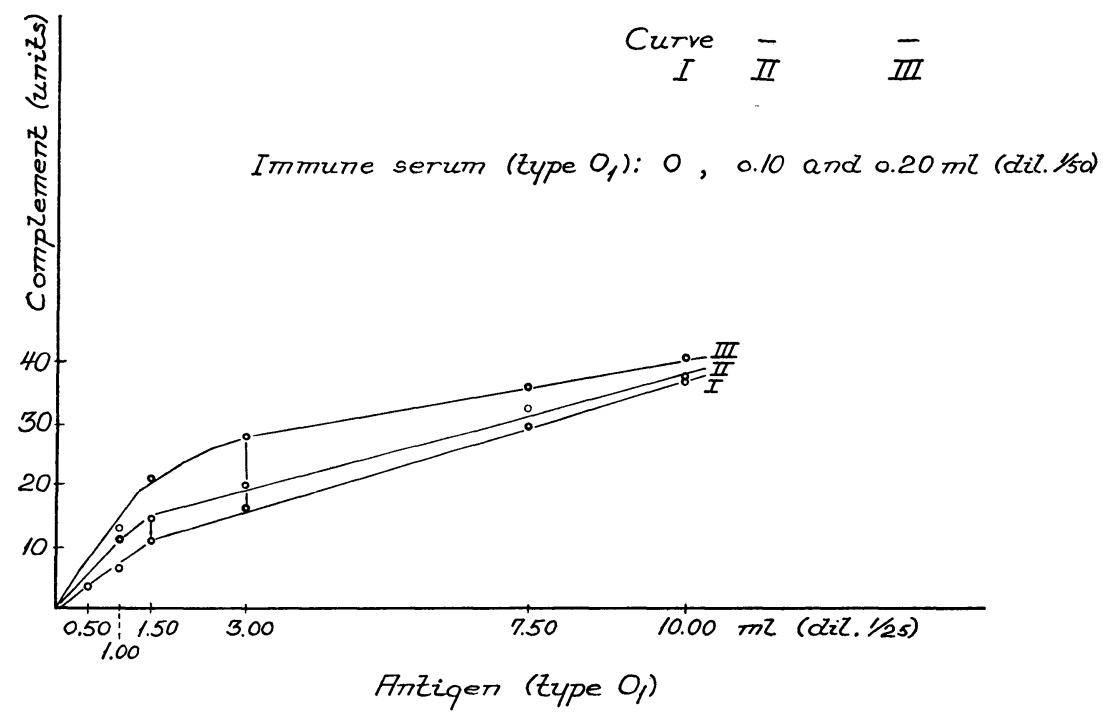

F i g. 1.

it appears that the determination of these optimum antigen quantities for the two arbitrarily chosen $O_{1}$-immune serum quantities ( 0.10 and $0.20 \mathrm{ml}$ ) is made by determining — using different quantities of $\mathrm{O}_{1}$-antigen - the specific + unspecific complement fixation of immune serum + antigen (curve II and III), and also the unspecific complement fixation of antigen alone (curve I). The number of complement units fixed in any single case is determined as described earlier. The same procedure is followed regarding $O_{1}$-immune serum and $O_{x}$-antigen 


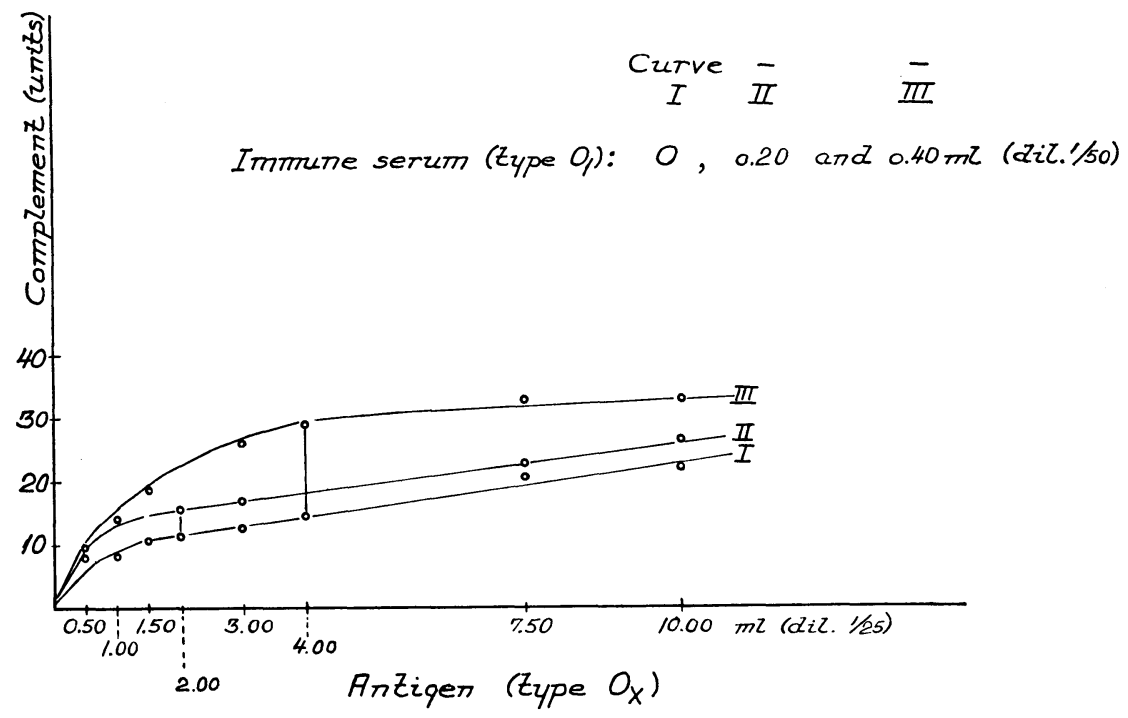

F i g. 2.

(fig. 2). The larger quantities of serum used here are necessary because of the heterologous relation of antigen and serum.

As there is an approximately linear relation between the chosen quantities of immune serum and the optimum quantities of antigen corresponding to the former, it will be possible graphically to find the optimum quantities of antigen corresponding to other arbitrarily chosen quantities of immune serum. The two first chosen quantities of immune serum and the observed corresponding optimum quantities of antigen are marked in a system of co-ordinates, after which a rectilinear curve is drawn for the reading of the optimum quantities of antigen of usually 3 other chosen quantities of immune serum.

With the 5 chosen quantities of immune serum and the corresponding optimum quantities of antigen (homologous or unknown) exact determinations are now made of the specific complement fixation of the quantities of immune serum. These determinations are made as shown in table 2.

As there is a linear relation between the connected values of immune serum and specifically fixed complement (SchjerningThiesen 1960), two rectilinear curves are drawn on the basis of the chosen quantities of immune serum and the complement units that are specifically fixed by these. These curves are used 


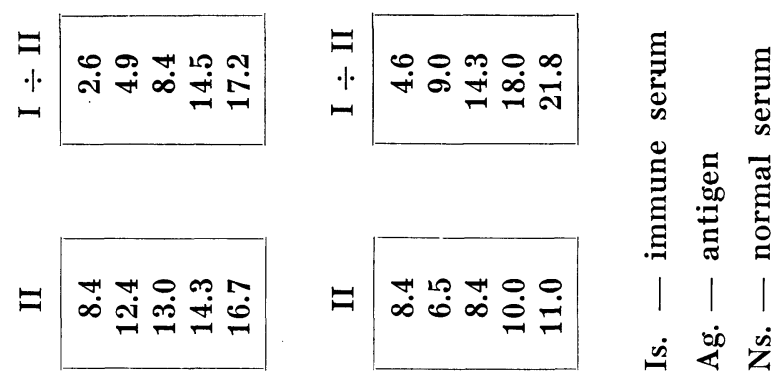

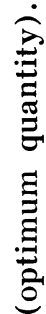

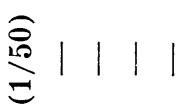

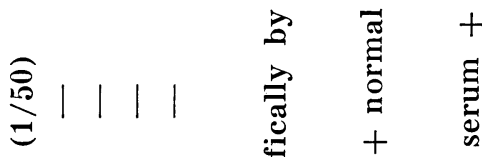

응 :

घं 1,1

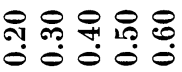

$\dot{s}, 1,1$

$++++$

$++++$

离 $0^{-1}$

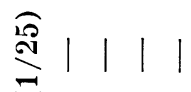

$+\stackrel{0}{\circ}$

เก

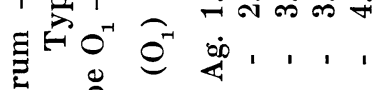

焉

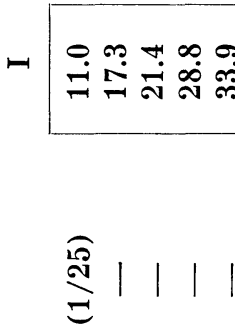

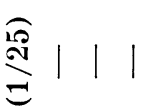

웅ㅇㅇㅇㅇㅇ

है

ง

एं , ' , '

氖

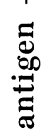

$+\quad \overrightarrow{2} 3$

$\stackrel{0}{\Xi}$

은

I- -

$0^{-1} \infty^{-1}, 1,1$

$++++$

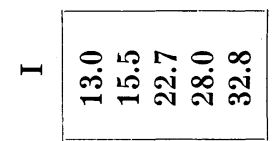

(ֶ)

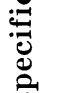

के है ठ

¿

空 $|1|$

읍 ำ ำ ำ ำ

0
0
$\dot{0}$

$\stackrel{\text { Iิ }}{=}|1|$

ช

ख 11,1

$+++t$

Е

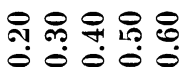

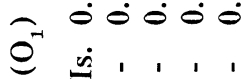

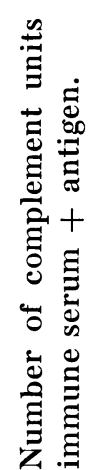

苛

눙

ไั่

हี่

$\ddot{\Xi}$

$\ddot{\sim} \ddot{\boxminus} \quad$

芯

胥 


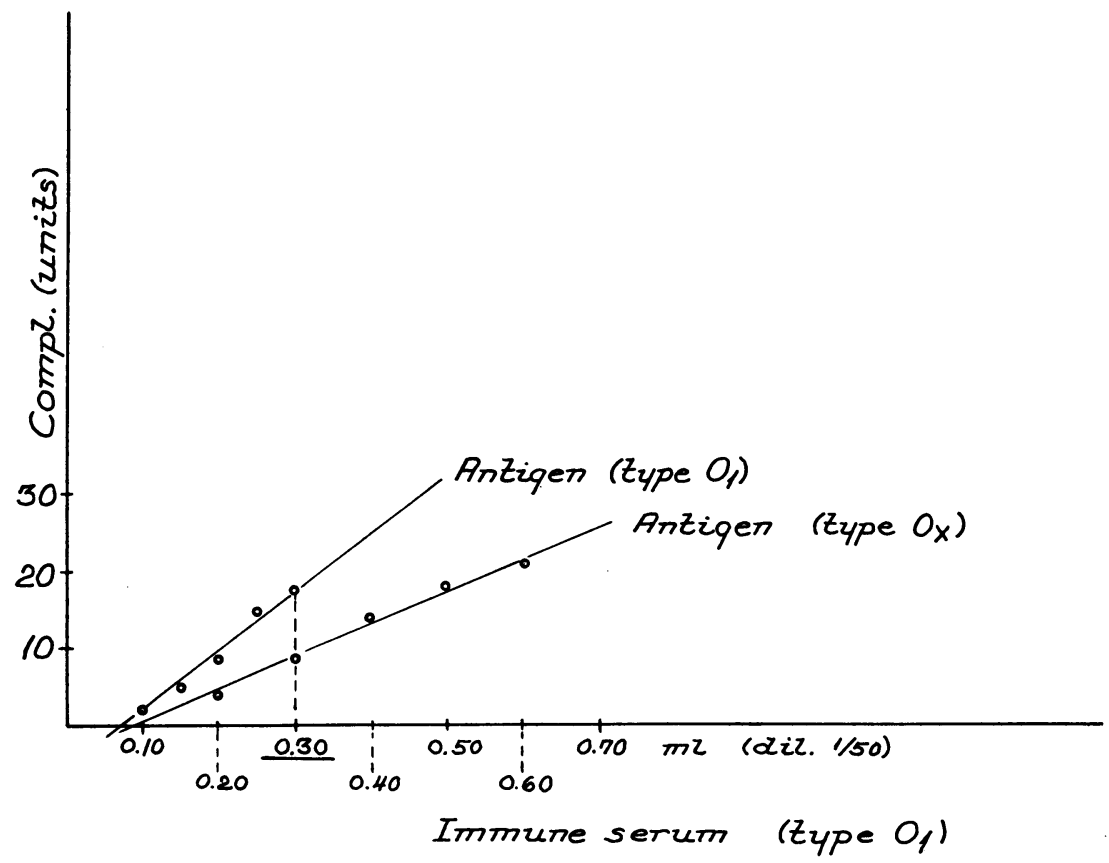

F i g. 3.

to read the activity ${ }^{\star}$ ) of immune serum with homologous and unknown antigen respectively (fig. 3).

If the activity is found to be the same with the two antigens, the $\mathrm{O}_{\mathrm{x}}$-antigen is declared identical with the $\mathrm{O}_{1}$-antigen. If not, i.e. in case of less fixation with the $\mathrm{O}_{\mathrm{x}}$-antigen (as is here shown), the investigation is repeated with other serum $\left(\mathrm{O}_{2}, \mathrm{O}_{3}\right.$, etc.). If no identical reaction is found with any known serum, the antigen represents a new type.

The reliability of the described procedure is calculated to be $\pm 6.6 \%$. However, a reliability margin of $\pm 10 \%$ is always observed. Thus a difference of more than $10 \%$ between the fixed complement units is regarded as being serologically significant; and a verification by means of an immune serum homologous with the unknown antigen is not considered necessary.

*) The standard of activity is indicated as the number of complement units fixed specifically by the largest quantity of applied immune serum in combination with homologous antigen. In the above example this quantity of serum is $0.30 \mathrm{ml}$, and the fixed complement units are 17 and 9 respectively. 


\section{CONCLUSION}

The greater reliability of the described method is based principally on the application of optimum quantities of antigen and on the exact determinations of both specific + unspecific and unspecific fixation. Also the elimination of accidental errors through the rectilinear serum curve is of importance. The greater technical sensibility obtained by the chosen incubation periods and temperatures as well as the spectrophotometrical measuring of the hemolysis degrees applying the wave length 523 microns likewise are contributing to the improved precision.

Using the described method it is not only possible to recognize minor serological differences with certainty, i. e. to differentiate "closely-related" types, but also to diagnose a new type more quickly, because verifying investigations with an immune serum produced from the unknown antigen are unnecessary. The demonstration of such a new type will of course induce a production of an immune serum as mentioned, but this production will not delay the type diagnose.

\section{REFERENCES}

1. Fisher, R. A. \& F. Yates: Statistical Tables. Edinburgh 1943.

2. Hallmann, L.: Bakteriologie und Serologie. Stuttgart 1950.

3. Leschly, W.: Studier over Komplement. Aarhus 1914.

4. Mayer, M. M., A. G. Osler, O. G. Bier \& M. Heidelberger: Activating effect of magnesium and other cations on hemolytic function of complement. Jour. Exp. Med. 1946, 84, 535-548.

5. Mayer, M. M., A. G. Osler, O. G. Bier \& M. Heidelberger: Quantitative studies of complement fixation. A method. Jour. Immunol. 1948, 59, 195-206.

6. Mayer, M. M., C. C. Croft \& M. M. Cray: Kinetic studies on immune hemolysis. Jour. Exp. Med. 1948, 88, 427-444.

7. Osler, A. G., J. H. Strauss \& M. M. Mayer: Diagnostic complement fixation. A method. Amer. Jour. Syphil., Gonorr. and Veneral. Dis. 1952, 36, 140-153.

8. Rice, C. E. \& P. Boulanger: A note on seasonal fluctuations in the complement titre of guinea pig serum. Canadian Jour. Comp. Med. and Vet. Sci. 1950, 14, 296-297.

9. Schjerning-Thiesen, K.: Oxyhæmoglobins omdannelse til methæmoglobin i komplementbindingsreaktionen. Nord. Vet.-Med. 1953, 5, 73-78.

10. Schjerning-Thiesen, K.: Experiments on the stability of sheep erythrocytes stored in Alsever's solution. Acta Path. et Microbiol. Scand. 1953, 32, 198-203.

11. Schjerning-Thiesen, $K$.: Complement fixation reaction of foot and mouth disease I. Acta vet. scand. 1960, 1, 294-299. 
12. Schjerning-Thiesen, $K$.: Complement fixation reaction of foot and mouth disease II. Acta vet. scand. 1960, 1, 300-304.

13. Stein, George J. \& Dang van Ngu: A quantitative complement fixation test: Titration of luetic sera by the unit of $50 \%$ hemolysis. Jour. Immunol. 1950, 65, 17-37.

14. Traub, E. \& H. Möhlmann: Typebestimmung bei Maul- und Klauenseuche mit Hilfe der Komplementbindungsprobe. Zentralbl. Bakt., Abt. I. 1943, 150, 289-300; 300-310.

15. Wallace, A. L., A. G. Osler \& M. M. Mayer: Quantitative studies of complement fixation. Jour. Immunol. 1950, 65, 661-673.

16. Whitmann, L.: Factors influencing the red cell agglutination inhibitive reaction in influenza and their application to the diagnostic test. Jour. Immunol. 1947, 56, 167-177.

\section{SUMMARY}

An improved complement-fixation technique in foot-and-mouth disease is described in details. In the development of the technique consideration has been given to the established presence of an antigenexcessphenomenon as well as to the linear relationship between amounts of immune serum used and complement fixed. The increased accuracy of the technique has made it possible more precise and rapid to detect even small serological differences.

\section{ZUSAMMENFASSUNG}

Typendifferenzierung bei Maul- und Klauenseuche (MKS).

Es wird eine detaillierte Beschreibung von einer bei Maul- und Klauenseuche angewendeten Komplementbindungstechnik gegeben. Diese Technik ist entwickelt mit Rücksicht-nahme auf die Anwesenheit eines Antigen-Überschussfänomenes, und auf die Feststellung von einer lineären Relation zwischen angewendeten Immunserummengen und die von diesen gebundenen Komplementmengen. Eine erreichbar grosse Genauigkeit ermöglicht kleine serologische Unterschiede (nähe verwandte Typen) mehr sicher und schnell zu erkennen.

\section{SAMMENDRAG}

Differentiering af virustyper ved mund-og klovesyge (mk).

Der gives en detailleret beskrivelse af en ved mund- og klovesyge anvendt komplementbindingsteknik. Omtalte teknik er udviklet under hensyntagen til forekomsten af et antigenoverskudsfænomen såvel som på erkendelsen af en lineær relation mellem anvendte immunserummængder og de af disse bundne komplementmængder. En opnåelig stor nøjagtighed $\mathrm{g} \emptyset \mathrm{r}$ det muligt sikkert og hurtigt at erkende endog små serologiske forskelle, d. v. s. „nærtbeslægtede“ typer. 